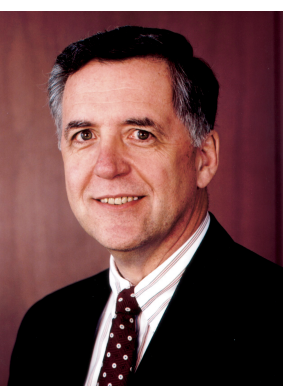

By Dale Bosworth

\title{
A Century of Rangeland Conservation in the Forest Service
}

The Forest Service has built a rich history of rangeland management and research since its inception a century ago. In fact, the original law governing the administration of national forest system lands, the Forest Service Organic Administration Act of 1897, requires that rangelands be managed for their protection and improvement. Hundreds of Forest Service rangeland conservationists and research scientists have tirelessly worked to support the tenets of this 1897 act by managing these lands for sustainability and various ecosystem services.

On November 8-10, 2004, a centennial forum was held on the Colorado State University campus in Fort Collins, Colorado, celebrating a "Century of Service" by the Forest Service and highlighting broad goals for better rangelands, wildlife, and fisheries management (http://www.fs.fed.us/r2/centennial/). Forum speakers not only acknowledged the past, but also explored how the Forest Service can better serve the public while caring for land in the 21st century. The manuscripts in this issue of Rangelands represent a cross section of presentations made at the Forum. Delegates Bob Budd, Ellie Towns, and Ed Marston, who represented the Centennial Forum at the Centennial Forest Congress in Washington, DC, this past January (http://www.fs.fed.us/newcentury/), wrote three of the articles.

The Forest Service stands committed to the mission of sustaining the ecological status, diversity, and productivity of our nation's forests and rangelands so they can meet the needs of present and future generations. As the following papers report, we are concerned not only with the ecological health of our nation's rangelands but also with the social and economic factors concerning rangelands that lend strength and stability to our country. I appreciate the participation of the Society for Range Management, along with other institutions, nongovernment organizations, and agencies in both the Centennial Forum and the Centennial Congress. Clearly, the journey to a future of sustainable rangeland management can only be achieved if it involves collaboration between those who understand and manage our land resources.

Author is Chief, USDA Forest Service, Washington, DC 20250. 